DOI https://doi.org/10.18551/rjoas.2017-06.24

\title{
IMPACT OF AGRICULTURAL PROGRAMMES ON SMALLHOLDER FARMERS' INCLUSIVE GROWTH IN SOUTHWEST NIGERIA
}

\author{
Olofinsao Abiodun, Sekumade Adelomo, Ajiboye Abiodun \\ Department of Agricultural Economics and Extension Services, Ekiti State University, \\ Ado-Ekiti, Nigeria \\ E-mail: tosinolofin14@gmail.com
}

\begin{abstract}
This study was conducted to examine inclusive growth in agricultural projects, among smallholder farmers in Southwest, Nigeria. The study specifically describes the socioeconomic characteristics of the smallholder farmers, estimates the determinants of inclusiveness of smallholder farmers in agricultural projects, measures the effectiveness of the features of Agricultural projects in supporting inclusive growth, and determines the effects of growth in the projects on farmers' productivity. A multi-stage sampling technique was used. Primary data were collected with the aid of well-structured questionnaire from ninety (90) participants and ninety (90) non-participants of three agricultural projects (FADAMA, Root and Tuber Expansion Programme and National Programme for Food Security) with guided interview. Data were analyzed using descriptive analysis, tobit regression, social opportunity function and t-test analysis. It was gathered from the study that most of the smallholder farmers were male (72.8 percent) with mean age of 50.9 years, they have relatively high household size of 9.0 . Over 80.0 percent of the smallholder farmers had access to primary education, the mean years spent in formal education was 7.5. They have spent average of 18.4 years in farming, with standard deviation of 9.1 . It was also discovered that they have access to market (60.6 percent), agricultural information (66.1 percent) and credit (52.2 percent). Farm size, educational level, farm experience, access to market, agricultural income, access to credit, access to agricultural information have positive likelihood of increasing the level of inclusiveness. But age and farm distance were negatively related. Factors that significantly affect inclusiveness among smallholder farmers were access to market at 10 percent (co efficient $=0.3$ ), access to credit at 5 percent (co-efficient $=0.2$ ), farm experience at 5 percent (co-efficient $=0.2$ ), and agricultural income at 1 percent (co-efficient $=0.4$ ). Most of the opportunities of agricultural projects were not inclusive, except increase in income and gender equity. There was significant effect of growth on farmers' productivity. It was recommended that bottom-top approach should be used in executing agricultural projects, also capacity building should be encouraged among smallholder farmers. Smallholder farmers should be given easy access to market and credit as this will increase their level of inclusiveness in agricultural projects. The youths should be encouraged to go into farming, because they have enough strength to be included in emerging poverty reduction projects.
\end{abstract}

\section{KEY WORDS}

Inclusive growth, agriculture, programmes, smallholding, farmer.

The agricultural sector is crucial to achieving Nigerian's objective of inclusive growth and poverty reduction. The Government of Nigeria is aware of this and has been implementing programmes that aims at increasing agricultural production and reduce rural poverty and rural-urban inequalities.

The Nigeria revolutions have called for economic inclusiveness and greater social justice. Achieving these objectives requires paying closer attention to poorer and less developed regions that mainly depend on agriculture (directly or indirectly) for livelihood. This is particularly relevant for Southwest, Nigeria where the majority of the rural poor depend on agriculture for their living. 
In agriculture, inclusive growth means developing the agricultural sector in a way that generates broad-based benefits for rural populations while improving economic productivity and food security at the local and national levels (Dunn, 2014).

The basis for using inclusiveness in driving the welfare of smallholders is that better well-being can be realized through economic stability and capacity building which can be generated through inclusive growth. Southwest Nigeria, faces technical and institutional constraints, potentially limiting their inclusion in emerging projects. The growing importance of rural-urban linkages, structural change in many middle-income countries and overall increased demand for food and fodder globally manifest a big market opportunity for small producers (FAO,2009).

Smallholders are stakeholders with significant shares in agricultural resources, activities and outputs hence they should be included in growth (Hazell, et al., 2007; World Bank, 2008; Pingali, 2010; Salami, et al., 2010). In Southwest Nigeria, smallholders are targeted in new poverty alleviation programs because they own the bulk of production resources like land and livestock, they directly benefit from income and food supply growth; and they can efficiently use land and cheaper family labour. It is therefore inevitable for smallholders to be incorporated into growth in response to growing demand which current production cannot fulfill (Pinstrup-Andersen, et al., 1997; IFPRI, 2005).

In Nigeria, the benefits of growth have not reached the poor, despite government spending a huge amount on various agricultural programmes including poverty eradication programmes. Also, Nigeria still faces an ongoing challenge of making its decade-long sustained growth more inclusive, even though the country is rich in land, human and natural resources, the people are still considered to be poor as the National Bureau of Statistics figures indicate that national poverty incidence reduced from approximately 65.6 percent to about 54.4 percent between 1996 and 2004. However, with increase in absolute population from an estimated 115 million to 140 million between the two periods, this actually amounts to an increase in the population in absolute poverty from 75.4 million to 76.2 million between the two periods. Income poverty moved up from 28.1 percent in 1980 to 65.6 percent in 1996 before it returned to 54.4 percent in 2004, and as high as 69 percent in 2010.

The State and Federal governments of Nigeria has embarked on various projects aimed at reducing poverty among the citizenry. Some of which are: Fadama programme, National Rice Expansion Programme (NERICA), National Programme for Food Security, Youth in Commercial Agriculture Development Root and Tuber Expansion Programme. The programmes however, have not significantly influenced the productivity and the well-being of smallholders (Umeh et al., 2014). Reasons that could be adduced to this are poor project management, corruption in public offices, inconsistent and poor implementation of government policies, insufficient inclusiveness of smallholders, neglect of rural infrastructure, and rise of oil shipments (Sekumade, 2009).

The main objective of the study is to examine the inclusive growth in agricultural projects, among smallholder farmers in Southwest, Nigeria.

The specific objectives are to: describe the socio-economic characteristics of the smallholder farmers in Southwest Nigeria; estimate the determinants of inclusiveness of smallholder farmers in agricultural projects; determine the effectiveness of the features of the various agricultural projects in supporting inclusive growth among smallholders; determine the effects of growth in the projects on farmers' productivity.

\section{MATERIALS AND METHOD OF RESEARCH}

The Study Area. The study was carried out in Southwest Nigeria. The Southwest is made up of six states which are; Ekiti, Ondo, Osun, Ogun, Oyo and Lagos. There are two distinct seasons namely; rainy season (April-October) and dry season (November-March). The temperature ranges from $21-28$ degree centigrade $\left({ }^{\circ} \mathrm{C}\right)$ with high humidity and $33^{\circ} \mathrm{C}$ in dry season. Although, some parts of the zone are fairly urbanized, the greater majority of the population still lives in the rural areas and their major occupation is farming. 
Sampling techniques. A multi-stage sampling technique was employed to select the respondents. The first stage was the random selection of three states from the six states in Southwest Nigeria. The second stage involves the purposive selection of three (3) Local Governments Areas (LGAs) from each state. The third stage involves the purposive selection of two (2) communities from each LGA. The last stage involves the random selection of five (5) respondents that participated in the projects under review and five (5) respondents that did not participate in the projects, in a community making a total of twenty (20) respondents from each local government, sixty (60) respondents from each state and a total of one hundred and eighty (180) respondents from the three states. The purposive selections were made because, the Agricultural Programmes were executed out in certain farm settlements.

Analytical Techniques. Descriptive analysis was used to describe the socio-economic characteristics of smallholders. The descriptive analyses that were used include frequency count and percentages.

Tobit analysis was used to estimate the determinants of inclusiveness of smallholders in agricultural projects.

$$
Y_{i}=X_{1}, X_{2}, X_{3}, X_{4}, X_{5}, X_{6}, X_{7}, X_{8}, X_{9}, X_{10}, X_{11} \text {, }
$$

Where:

$Y_{\mathrm{i}}=$ level of inclusiveness in agricultural programmes;

$\mathrm{X}_{1}=$ Gender of $\mathrm{SH}$ (male $=1$, female $\left.=0\right)$;

$\mathrm{X}_{2}=$ Age of Smallholder farmer (SF) (years);

$\mathrm{X}_{3}=$ Education level of SF (years);

$\mathrm{X}_{4}=$ Household size (numbers);

$\mathrm{X}_{5}=$ Farm size (acres);

$X_{6}=$ Marital status (single $=1$, married $=2$, divorced $=3$, widowed $=4$ );

$\mathrm{X}_{7}=$ Access to Market (yes $=1$, otherwise $=0$ );

$\mathrm{X}_{8}=$ Experience of the $\mathrm{SH}$ (years);

$\mathrm{X}_{9}=$ Access to Credit (yes $=1$, otherwise $=0$ );

$\mathrm{X}_{10}=$ Income;

$\mathrm{X}_{11}=$ primary occupation

Social opportunity function was used to determine the effectiveness of the features of the various agricultural projects in supporting inclusive growth among smallholder farmers in Southwest Nigeria.

$$
d A O(p)=(E I) d Y^{*}(p)+Y^{*}(p) d(E I),
$$

Where:

$A O(p)=$ Opportunity Index;

$E I=$ Equity Index;

$Y^{*}(p)=$ Average opportunities.

$T$-test was used to determine the effect of inclusive growth in the projects on farmers' productivity.

The T-test Statistic was used to test the significant difference in the income between the participants and non-participants.

$$
T=\frac{\bar{x}_{1}-\bar{x}_{2}}{\sqrt{\frac{S_{1}^{2}}{n_{1}}+\frac{S_{2}^{2}}{n_{2}}}}
$$

Where:

$\bar{x}_{1}=$ mean income of the projects participants;

$\bar{x}_{2}=$ mean income of the projects non-participants;

$S_{1}^{2}=$ standard deviation of the participants; 
$S_{2}^{2}=$ standard deviation of the non-participants;

$n_{1}=$ sample size of the participants;

$n_{2}=$ sample size of non-participants.

Decision rule: there is no significant difference, if calculated T-value is less than table value of 1.96 at $5 \%$ level of significant in a two tailed T- test.

\section{RESULTS AND DISCUSSION}

\section{Socio-Economic Characteristics:}

Table 1 - Socio-economic Characteristics of Smallholder farmers

\begin{tabular}{|c|c|c|c|c|c|}
\hline \multirow{2}{*}{ Socio-economic characteristics } & \multicolumn{2}{|l|}{ Participants } & \multicolumn{2}{|c|}{ Non-participants } & \multirow[t]{2}{*}{ Total } \\
\hline & Frequency & Percentage & Frequency & Percentage & \\
\hline Gender & & & & & \\
\hline Male & 62 & 68.89 & 69 & 76.67 & 72.78 \\
\hline Female & 28 & 31.11 & 21 & 23.33 & 27.22 \\
\hline \multicolumn{6}{|l|}{ Age (years) } \\
\hline$<31$ & 5 & 5.55 & 3 & 3.33 & 4.44 \\
\hline $31-40$ & 15 & 16.67 & 18 & 20.00 & 18.34 \\
\hline $41-50$ & 22 & 24.44 & 14 & 15.56 & 20.00 \\
\hline $51-60$ & 27 & 30.00 & 22 & 24.44 & 27.22 \\
\hline $61-70$ & 14 & 15.56 & 32 & 35.56 & 25.56 \\
\hline$>70$ & 7 & 7.78 & 1 & 1.11 & 4.45 \\
\hline \multicolumn{6}{|l|}{ Marital Status } \\
\hline Single & 11 & 12.22 & 8 & 8.89 & 10.56 \\
\hline Married & 57 & 63.33 & 66 & 73.33 & 68.33 \\
\hline Divorced & 6 & 6.67 & 5 & 5.56 & 6.12 \\
\hline Widowed & 14 & 15.56 & 11 & 12.22 & 13.89 \\
\hline \multicolumn{6}{|l|}{ Household Size } \\
\hline$\leq 5$ & 14 & 15.56 & 11 & 12.22 & 13.89 \\
\hline $6-10$ & 42 & 46.56 & 32 & 35.55 & 41.16 \\
\hline $11-15$ & 30 & 33.33 & 39 & 43.33 & 38.33 \\
\hline$>15$ & 5 & 5.56 & 8 & 8.89 & 7.23 \\
\hline \multicolumn{6}{|l|}{ Educational level } \\
\hline No formal & 11 & 12.22 & 13 & 14.44 & 13.33 \\
\hline Primary & 35 & 38.89 & 41 & 45.56 & 42.23 \\
\hline Secondary & 38 & 42.22 & 34 & 37.78 & 40 \\
\hline Tertiary & 6 & 6.67 & 2 & 2.22 & 4.45 \\
\hline \multicolumn{6}{|l|}{ Agricultural Enterprise } \\
\hline Crops & 43 & 47.78 & 35 & 38.89 & 43.34 \\
\hline Animal & 22 & 24.44 & 24 & 26.67 & 25.5 \\
\hline Both & 25 & 27.78 & 31 & 34.44 & 31.11 \\
\hline \multicolumn{6}{|l|}{ Farm Size (Hectare) } \\
\hline $0-1$ & 25 & 27.78 & 44 & 48.89 & 38.34 \\
\hline $1-2$ & 33 & 36.67 & 27 & 30.00 & 33.34 \\
\hline $2-3$ & 32 & 35.55 & 19 & 21.10 & 28.33 \\
\hline \multicolumn{6}{|l|}{ Primary Occupation } \\
\hline Farming & 55.00 & 61.11 & 57.00 & 63.33 & 62.22 \\
\hline Civil service & 15.00 & 16.67 & 12.00 & 13.33 & 15.00 \\
\hline Artisanship & 8.00 & 8.89 & 18.00 & 20.00 & 14.45 \\
\hline Others & 2.00 & 2.22 & 3.00 & 3.33 & 2.78 \\
\hline \multicolumn{6}{|l|}{ Farming experience (years) } \\
\hline$<10$ & 12.00 & 16.33 & 23.00 & 25.56 & 20.95 \\
\hline $11-20$ & 46.00 & 51.11 & 43.00 & 47.78 & 49.45 \\
\hline $21-30$ & 14.00 & 15.56 & 16.00 & 17.78 & 16.67 \\
\hline $31-40$ & 12.00 & 10.33 & 5.00 & 5.56 & 7.95 \\
\hline$>40$ & 6.00 & 6.67 & 3.00 & 3.33 & 5.00 \\
\hline \multicolumn{6}{|l|}{ Types of labour } \\
\hline Family & 31 & 34.44 & 48 & 53.33 & 43.89 \\
\hline Hired & 34 & 37.78 & 30 & 33.34 & 35.56 \\
\hline Both & 25 & 27.78 & 12 & 13.33 & 20.56 \\
\hline \multicolumn{6}{|l|}{ Access to market } \\
\hline Yes & 62 & 68.89 & 47 & 52.22 & 60.56 \\
\hline No & 28 & 31.11 & 43 & 47.78 & 39.45 \\
\hline Access to credit & & & & & \\
\hline Yes & 55.00 & 61.11 & 39.00 & 43.33 & 52.22 \\
\hline No & 35.00 & 38.89 & 51.00 & 56.67 & 47.78 \\
\hline Access to extension & & & & & \\
\hline Yes & 44.00 & 48.89 & 29.00 & 32.22 & 40.5 \\
\hline No & 46.00 & 51.11 & 61.00 & 67.78 & 59.45 \\
\hline Income (\#) & & & & & \\
\hline$<100,000$ & 30 & 33.33 & 54 & 59.89 & 46.11 \\
\hline $100,001-200,000$ & 45 & 50.00 & 25 & 27.78 & 38.89 \\
\hline $200,001-300,000$ & 8 & 9.17 & 9 & 10.00 & 9.59 \\
\hline $200,001-400,000$ & 5 & 5.55 & 3 & 3.30 & 4.43 \\
\hline$>400,000$ & 2 & 2.22 & 0 & 0.00 & 1.11 \\
\hline
\end{tabular}

Source: Field Survey, 2016. 
The socio-economic characteristics of smallholder farmers used in this study range from gender, age, marital status, household size, educational level, agricultural enterprise, primary occupation, farming experience, types of labour, access to market, access to credit, access to extension and income.

From Table 1, it is revealed the smallholder farmers were mainly male $(72.78 \%)$ and they are between the ages of 51 and $70(52.78 \%)$. This may be as a result that, the socioeconomic and cultural environment of the southwest, Nigeria gives men major responsibilities of providing for the households. And as a reason of their age, they will be able to engage in various agricultural activities. This is consistent with the findings of Onyemauwa, et.,al (2013).

Most $(68.33 \%)$ of the smallholder farmers were married with relatively large household size of 6-10. This is an indication that they will be willing and able to participate in Agricultural programme, since they have large family members to help them on the farm.

There is high literacy rate among the farmers, as indicated in Table 1, that $86.68 \%$ of the farmers had formal education. Their formal education is said to boost their participation in agricultural programmes.

Agricultural enterprises surveyed under this study were crop production and animal production. It is discovered from the study $43.34 \%$ of the smallholders farmers were into solely crop production. This may be as a result that $84.22 \%$ of the foods consumed by man are crop sources. The implication is that, they are more likely to participate in agricultural projects aimed at crop production.

A smallholder farm ranges from 0.1 to 3 Hectares (FAO, 2009). The distribution in Table 1 , shows that majority $(38.34 \%)$ of the farmers operated their farming activities on farmland less than 1 hectares. But, distinctively the participating farmers operated more on 12 hectares of farmland, while the non-participating farmers operated on 0-1 hectare of farmland.

The primary occupation engaged by the farmers was farming (62.22\%). Though other farmers agreed that civil service, artisanship were their primary occupation. This is consistent with a-prior expectation that the major occupation in the rural areas is farming. The indication is that the smallholder farmers will be able to participate in the agricultural programmes, thus they will be included in growth.

It is revealed from this result that the modal years of farming experience is between 11 and 20. This is expected to positively influence their inclusiveness in Aps.

The type of labour used by the smallholder farmers was mainly family $(43.89 \%)$. This implies that farmers prefer family labour to hired labour, and this is would make the farmers to participate in the projects, since the money that should be spent on hired labour will be used for more profitable venture.

The result further revealed that the smallholder farmers had access to market $(60.56 \%)$, access to credit $(52.22 \%)$, and no access to extension service $(59.45 \%)$. The accessibility of the farmers to market and the credit are expected to improve their willingness and ability to participate in agricultural projects, thus, been included in growth. But, the smallholder farmers opined that they do not have access to extension services, this has a tendency of reducing their participatory ability in agricultural programmes.

The income of the smallholder farmers varied from $<\# 100,000$ to $\#>400,000$. The half of the participating farmers had between $\# 100,000$ to $\# 200,000$, while $46.11 \%$ of the nonparticipating farmers had less than $\# 100,000$. The difference in their annual income is mainly because the participation in the agricultural programmes.

Determinants of Inclusiveness in Agricultural projects among Smallholder Farmers. The table 2 shows the determinants of inclusiveness in Agricultural projects. The $\mathrm{R}^{2}$ value from the result showed that the predictors (independent variables) can account for $92 \%$ of the variation in the dependent variable (level of inclusiveness), while the unexplained variance (error term) can be accorded to $8 \%$. It was gathered that all the independent variables had positive relationship with the level of inclusiveness among smallholder farmers, except for household size, age and farm distance. 
The majority of the respondents for this study were males (Table 1). The result from Table 1 revealed that an increase in the number of males involved in production, will lead to 0.087 increase in the level of inclusiveness. Furthermore, a rise in the number of years the smallholder farmer spent in formal education will result to 0.009 increase in inclusiveness in the agricultural projects. This may be due to the fact that, as the farmers gain more knowledge and skills, it tends to increase their propensity to practice what they were taught and they are more likely to cope with new technologies that were provided by the projects. This is consistent with a-prior expectation, also Taiwo and Omifolaji (2015), reported that education positively affect the level of inclusiveness of farmers.

An increase in a hectare of farm will lead to 0.0459 increase in the level of inclusiveness, this conforms with the a-prior expectation. Access to agricultural information, access to extension, access to market and access to credit have been shown to positively influence the level of inclusiveness these are correct with the a-prior expectation. Access to market is significant at $10 \%$ level and access to credit is significant at $5 \%$ level. This finding is in line with that of Edi et al. (2007) who noted that access to credit, farm size and contact with extension influence inclusiveness in Agricultural programmes. Also, Etwire et al., (2013) reported that credit access is one of the major factors influencing inclusion in agricultural projects.

Primary occupation, farming experience and income have also been revealed to have positive likelihood with level of inclusiveness in agricultural projects. The primary occupation was farming, and from table 10 it has positive likelihood with the level of inclusiveness having a co-efficient of 0.024 , this is consistent with the expected relationship. This shows that an increase in the number of people primarily engaged in farming, there is maximum likelihood that the level of inclusiveness will increase by 0.024 . Since, that is their main source of livelihood, they wish to expand it and increase their production, to create opportunities for themselves in order to meet their socio-economic needs.

Farming experience has been revealed to have positive likelihood with the level of inclusiveness of the smallholder farmers' and statistically significant at 5 percent. A rise in the number of years smallholder farmers spent in farming will raise the level of inclusiveness by 0.203. This may be because they have experienced the ups and downs in agriculture over the years, and thus have learnt from the experiences. And are now willing to expand the gain or mitigate the losses through inclusion in the projects. Also, Ugwoke et al., (2015); Nwaobiala (2014), noted that farm experience is a significant factor, which positively relates to participation in agricultural project.

Table 2 - Determinants of Participation in Agricultural programmes among Smallholder Farmers

\begin{tabular}{llll}
\hline Variables & Co-efficient & Standard Error & T value \\
\hline Gender & 0.0871 & 0.0597 & 1.4590 \\
Age & -0.0009 & 0.0030 & -0.3000 \\
Educational level & 0.0094 & 0.0345 & 0.2725 \\
Household size & -0.0008 & 0.0082 & -0.0976 \\
Farm size & 0.0459 & 0.0376 & 1.2207 \\
Marital status & 0.0401 & 0.0333 & 1.3784 \\
Access to market & $0.2699^{*}$ & 0.1554 & 1.7368 \\
Farm experience & $0.2027^{* *}$ & 0.0917 & 2.2105 \\
Access to credit access & $0.1603^{* *}$ & 0.0750 & 2.1373 \\
Income & $0.4358^{* * *}$ & 1.58 & 2.7620 \\
Primary occupation & 0.0242 & 0.0307 & 0.7883 \\
Constant & -0.5836 & 0.2574 & -2.2673 \\
/sigma & 0.1934 & 1.2657 & 0.1529 \\
\hline
\end{tabular}

Tobit regression result:

$R 2=0.9215$, No of observations $=90$, LR Chi $2(16)=104.88$, Prob. $>$ chi2 $=0.0000$.

${ }^{* * *}$, ${ }^{* *}$ and ${ }^{*}$ represents $1 \%, 5 \%$ and $10 \%$ level of significance level.

Source: Field Survey, 2016.

From the result, an increase in agricultural income, indicate maximum likelihood to have 0.436 increases in the level of inclusiveness in agricultural projects and it is statistically 
significant at 1 percent. This result conforms to the a-prior expectation and to the study of Bagherian et al., (2009), who noted that income level is significant and has positive relationship with inclusiveness of farmers in agricultural programs.

On the other hand, an increase in the household size, will lead to 0.001 decrease in the level of inclusiveness, this may be because the household head focuses primarily on providing food for his family and having no or little thought about expansion of his enterprise. This result follows the a-prior expectation.

Age of the smallholder farmers, influences the level of inclusiveness with negative maximum likelihood of 0.001 . An increase in the age of the farmer, there will be 0.001 decrease in the level of inclusiveness in agricultural projects. This may be because, the farmers will not want to stress himself or herself much, since he or she is getting older and only has a sole responsibility of providing food for his family. This is against the a-prior expectation, but in accordance with the studies of Bagherian et al., (2009); Sulo et al., (2012) who noted that age and household size have negative relationship with participation in agricultural projects.

Farm distance is said to be adversely related to the level of inclusiveness in agricultural projects. The farer the farm by 1 Kilometer, the more likelihood that the farmers level of inclusiveness in agricultural projects will be reduced by 0.004 .

Effectiveness of the features of the various agricultural projects in supporting inclusive growth among smallholders. The features are grouped into three main opportunities namely; growth expansion and economic opportunities, social inclusion and access to basic infrastructural and human development opportunities, and social safety nets.

Growth Expansion and Economic Opportunities. Table 3, shows the inclusive growth expansion and economic features of the agricultural projects. This study reports that all these features are not inclusive except income, which recorded opportunity index of 93.20 and equity index of 1.03. This shows that increase in income is equal among the smallholder farmers. This equality in increase in income among smallholder farmers, is because the income-gap among them is minimal, they are majorly peasant farmers. But, for other economic growth and expansion features were majorly experienced by the smallholder farmers with higher income level. This is consistent with the a-prior expectation and with the study of Ali and Son (2007) who noted that economic growth has not be inclusive.

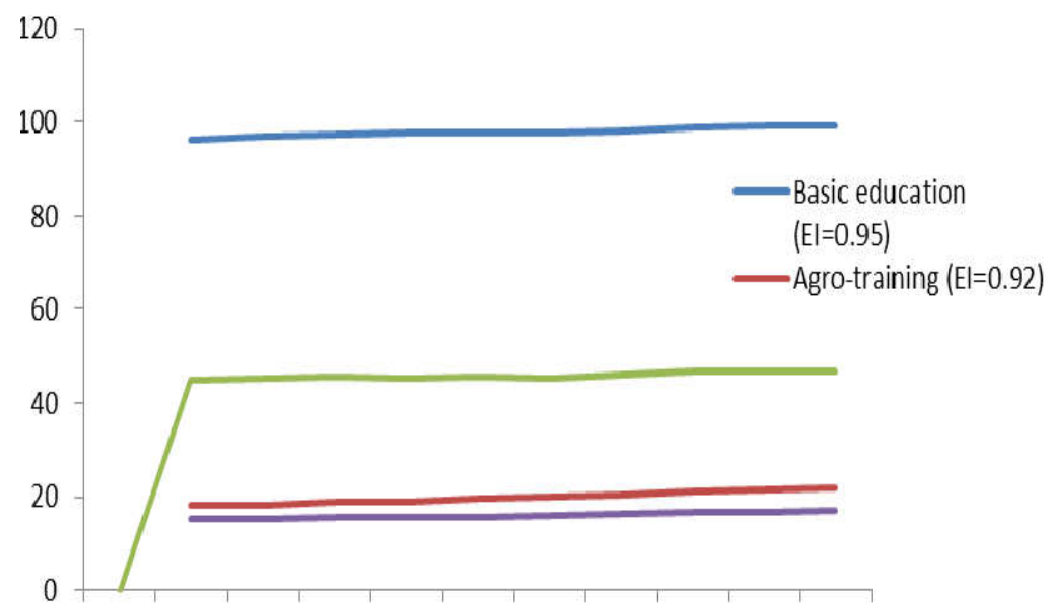

Figure 1 - Inclusive Report Based on Social inclusive and Access to Basic Opportunities Source: Field Survey, 2016

Social Inclusion and Access to Basic Infrastructural and Human Development Opportunities. Social inclusion ensures that all sections of the population, including those disadvantaged due to their individual circumstances, have equal access to opportunities.

Figure 1 shows the inclusiveness of the features of the agricultural projects based on their social inclusion and access to basic opportunities. They include; access to basic education, agro-training, agro-technology and good water supply. The progressive 
movement of the opportunity curve showed in figure 1 indicates that the opportunities were mainly enjoyed by the smallholders with higher income, that means it is not pro-poor. Though, they have access to these basic opportunities, but none is inclusive, the equity indices were lesser than 1. This is consistent with the findings of Ali and Son (2007) and Ajiboye and Osundare (2015).

Table 3 - Inclusive Report Based on Growth Expansion and Economic Opportunities

\begin{tabular}{lllllll}
\hline $\begin{array}{l}\text { Population } \\
\text { share/ features }\end{array}$ & $\begin{array}{l}\text { Increase in } \\
\text { income }\end{array}$ & $\begin{array}{l}\text { Increase in } \\
\text { savings }\end{array}$ & $\begin{array}{l}\text { Increase in } \\
\text { wages and } \\
\text { salaries }\end{array}$ & $\begin{array}{l}\text { Increase in } \\
\text { Farm size }\end{array}$ & $\begin{array}{l}\text { Increase in } \\
\text { Farm output }\end{array}$ & $\begin{array}{l}\text { Increase in } \\
\text { Farm } \\
\text { enterprise }\end{array}$ \\
\hline 10 & 95.75 & 89.08 & 30.80 & 45.72 & 55.6 & 37.38 \\
20 & 95.36 & 91.49 & 33.39 & 46.25 & 61.1 & 37.14 \\
30 & 94.91 & 92.71 & 35.07 & 46.73 & 63.0 & 38.19 \\
40 & 94.42 & 93.57 & 36.81 & 46.97 & 61.1 & 39.37 \\
50 & 93.95 & 94.24 & 38.06 & 47.52 & 62.2 & 40.60 \\
60 & 93.31 & 94.96 & 38.86 & 47.88 & 63.0 & 41.38 \\
70 & 92.76 & 95.39 & 39.89 & 47.97 & 65.1 & 42.27 \\
80 & 91.78 & 95.80 & 41.27 & 48.32 & 64 & 43.23 \\
90 & 90.45 & 96.16 & 42.62 & 49.43 & 65.4 & 44.15 \\
100 & 89.39 & 96.14 & 44.31 & 51.02 & 68.9 & 45.60 \\
OI & 93.20 & 94.07 & 40.93 & 47.78 & 62.94 & 40.93 \\
El & 1.03 & 0.97 & 0.90 & 0.96 & 0.88 & 0.90 \\
\hline Decision & $\mathrm{I}$ & $\mathrm{NI}$ & $\mathrm{NI}$ & $\mathrm{NI}$ & $\mathrm{NI}$ & $\mathrm{NI}$ \\
\hline
\end{tabular}

Source: Field Survey, 2016

Social Safety Nets. Social safety nets are required to protect the chronically poor and to mitigate the risks and vulnerabilities associated with transitory livelihood shocks, caused for example by ill health or economic crisis.

Figure 2, shows the opportunity curve for the features of agricultural projects based on their social safety nets. The features include gender equity, income class equity and proper organization. The downward slope of gender equity indicates that the opportunity is pro-poor (that is, it is more enjoyed by the poorer smallholders). While the upward slope of the income equity and proper organization means that the opportunities were not pro-poor. The equity index of gender equity is 1.37 , implicating that it is inclusive. Income class equity and organization were not inclusive as indicated by the opportunity curve and the equity index. This may have been a result that the projects were gender sensitive, but for the income class and organization they were not, probably the projects were drifted mostly to those with higher income. Also, the organizations of the projects could be biased.

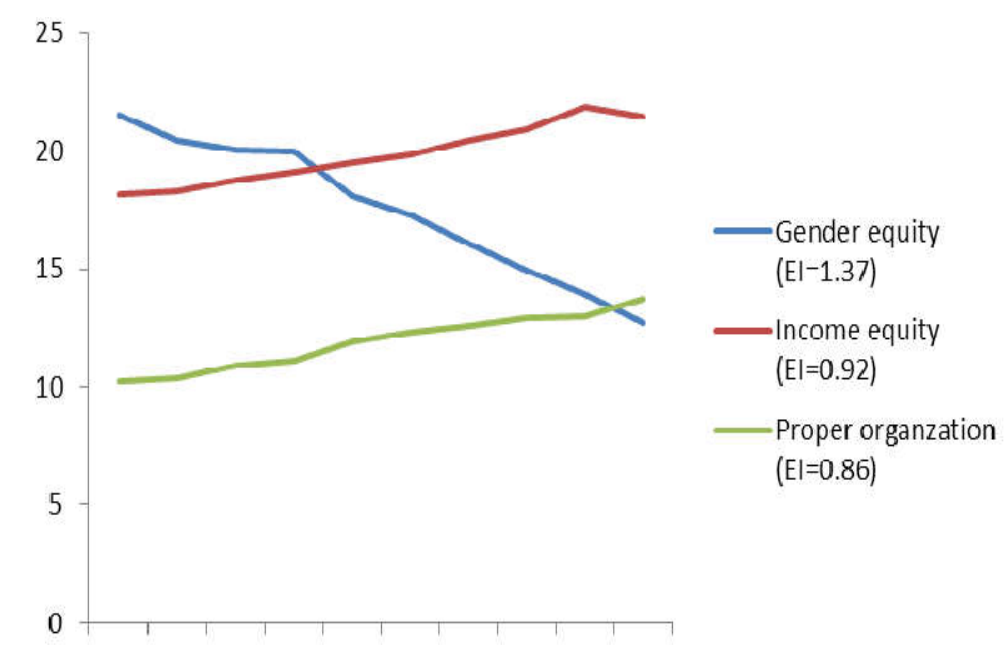

Figure 2 - Inclusive Report Based on Social Safety Nets Source: Field Survey, 2016 
The Effects of Inclusive Growth on Smallholder Farmers' Productivity. From table 4, Participants' income is significantly different from Non-Participants' income, $t$ stat. $=2.96, p<$ 0.01 . The result is $99 \%$ confident that the mean difference lies between 16233 and 239540 . It is discovered that the mean income for the participants is $\$ 229,360$, while for the nonparticipants is $\mathrm{A} 117,707$.

Table 4 - Effects of Inclusive growth in Agricultural Projects on Smallholder Farmers' Productivity

\begin{tabular}{|l|l|l|l|}
\hline \multicolumn{5}{|c|}{ Descriptive Statistics } \\
\hline n/n & Mean & Standard Deviation & Number \\
\hline Participants & N229,360 & N 120,016 & 90 \\
\hline Non- Participants & $\mathbb{N} 117,707 \quad$ Independent Samples t-Test \\
\hline \multicolumn{4}{|l|}{90} \\
\hline t-Statistic & $2.9547 \quad 2.7633$ & \\
\hline Critical Value & $2.16233 .1523,239539.8189]$ \\
\hline $99 \%$ Confidence Interval & {$[-164$} & \\
\hline
\end{tabular}

Source: Field Survey, 2016

This shows that there is significant difference in their productivity as measured by their income. The result is statistically significant at $1 \%$ level, with confidence level of $99 \%$. The critical value is 2.76 and since the calculated $t$ value is 2.96 , which is greater than 2.76 , it implies that there is significant difference in the mean income of the participants and the nonparticipants and also the result can be relied upon. The significant difference can be due to access of agricultural information, market, extension services and credit. As Ekong (2003) rightly said that credit is a very important factor to increase and expand farm enterprise.

\section{CONCLUSION AND RECOMMENDATIONS}

Agricultural projects have been a welcome development by various governments at different stages as they were targeted to reduce poverty and increase the welfare of the rural populace especially the farmers. But, these goals and objectives have been dashed and have not been inclusive (in terms of opportunities they offered) among smallholder farmers in southwest Nigeria, as it has been indicated by the social opportunity function. Though the farmers experience growth and expansion in their enterprises, and they had access to basic infrastructure and human development opportunities, but the access and growth did not cut across all the smallholder farmers.

Also, there are differences between inclusiveness and non-inclusiveness in agricultural projects and the factors that influence their inclusion were known to be farm experience, access to market, access to credit facilities and income.

The study recommends:

Efforts should be intensified to enable more smallholder farmers benefit from the projects. One of the ways this can be done is to make the projects embrace a bottom-top approach that is farmers should be involved in planning and organization of the projects.

Basic infrastructure and human development, such as training and agro-technology have a great tendency in building the capacity of farmers, thus smallholder farmers should be allowed to have equal access to them.

Agricultural credit institutions should be localized in rural areas to increase accessibility to smallholder farmers.

Credit agencies and institutions should have flexible conducts to encourage the smallholder farmers to access credit for expanding their enterprises.

\section{REFERENCES}

1. Ajiboye A. and Osundare F. O. (2015). Comparative Analysis of Fertilizer Use among Small-Scale Irrigation Farmers in North-Western Nigeria. IOSR Journal of Agriculture and Veterinary Science (IOSR-JAVS) Volume 8, Issue 11 Ver. II (Nov. 2015), pp. 01-07 
2. Ali, Ifzal and H. Hwa Son, (2007). Measuring Inclusive Growth, Asian Development Review, Vol. 24, No. 1, pp.11-31.

3. Bagherian, R., A.S. Bahaman, A.S. Asnarulkhadi and A. Shamsuddin (2009). Factors Influencing Local People's Participation in Watershed Management Programs in Iran. Journal of Economics and Sustainable Development, Vol.4, No.10, 2013

4. Dunn, Elizabeth (2014). Facilitating Systemic Change in Value Chains: Lessons Learned for Strengthening Country Systems: Background Paper for the USAID Experience Summit on Strengthening Country Systems. USAID Learning Lab website, pg. 4

5. Edi, D., Paola, G., Ford, R. and Samuel, T. (2007). Factors Affecting Farmer's Participation in Agro-environmental Measures: A Northern Halian Perspectives. Journal of Agricultural Economics, Princeville Publishers, Rome, Italy 59(1), Pp. 114-131.

6. Ekong E.E (1996). An Introduction to Rural Sociology. Jumak Publishers Ltd. Ibadan, Nigeria, pp. 57-61.

7. Etwire, P. M., W. Dogbe and S. K. Nutsugah (2013). Institutional Credit Available to Smallholder Farmers in the Northern Region of Ghana. International Journal of AgriScience In press.

8. Food and Agriculture Organization (FAO) (2009). How to feed the world by 2050. USA: FAO.

9. Hazell P., Poulton C., Wiggins S., and Dorward A (2007). The Future of Small Farms for Poverty Reduction and Growth. 2020 Discussion Paper No. 42. IFPRI, Washington, D.C.

10. International Food Policy Research Institute (IFPRI) (2005). The future of small farms: Proceedings of a research workshop, Wye, UK, June 26-29, Washington, DC

11. Nwaobiala, C. U., (2014). Socio-economic factors influencing farmers' participation in community-based programme in Abia and Cross River States of Nigeria. Journal of Agricultural Extension. Vol. 18, No.1, pp.48-61.

12. Onyemauwa, C.S. et al (2013). Household Poverty Status and Child Labour Participation in Isoko North of Delta State, South-South Nigeria. International Journal of Agricultural and Food Science, Vol. 3(3): 80-85 May

13. Pingali P.L. (2010). Agriculture Renaissance: Making "Agriculture for Development" Work in the 21st Century. Handbook Agric. Econ. 4:3867-3894.

14. Pinstrup-Andersen P, Pandya-Larch R, Rosegrant MW (1997). The world food situation: recent developments, emerging issues, and long-term prospects. Consultative Group on International Agricultural Research International Centers Week Washington, D.C., 1997.

15. Salami A, Kamara AB, Brixiova Z (2010). Smallholder Agriculture in East Africa: Trends, Constraints and Opportunities, Working Papers Series $N^{\circ} 105$ African Development Bank, Tunis, Tunisia.

16. Sekumade A.B. (2009). The effect of petroleum dependence on agricultural trade in Nigeria: An error correlation modeling (ECM) approach.

17. Sulo T. et al (2012). Socioeconomic Factors Affecting the Adoption of Improved Agricultural Technologies among Women in Marakwet County Kenya Journal of Emerging Trends in Economics and Management Sciences (JETEMS) 3(4): 312-317

18. Taiwo, A. M. and Omifolaji, J. K. (2015). Impact Assessment of National Programme for Food Security (NPFS) On Farmers' Production in Oyo State. PAT December, 2015; 11 (2): 132-142 ISSN: 0794-5213

19. Ugwoke, F.O., Adesope, O.M. and Ibe, F.C. (2005). Youths Participation in Farming Activities in Rural Areas of Imo State, Nigeria. Implications for Extension. Journal of Agricultural Extension. 8:136-141

20. Umeh G.M, Chukwu V.A and Anyigor O.A. (2014). Level of participation and benefits of National Programme for Food Security (NPFS) among rural women in Ebonyi State. Global Journal of Agricultural Research. Vol. 2, No. 4, pp19-26

21. World Bank (2008). World Development Report 2008: Agriculture for development. 1818 H Street, NW, Washington, DC 20433, USA. 